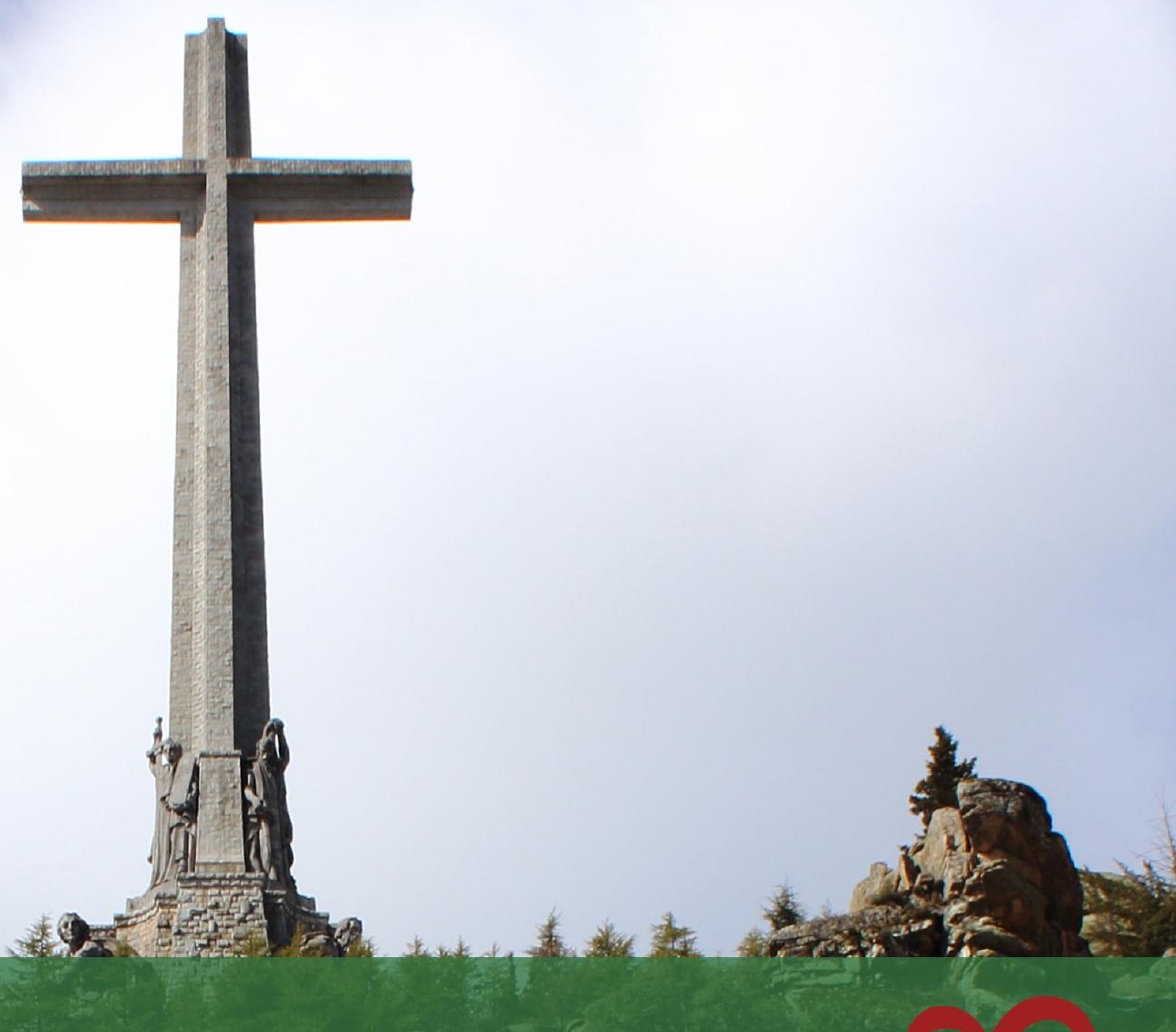

Revista digital de Ciencia y Didáctica de la Historia

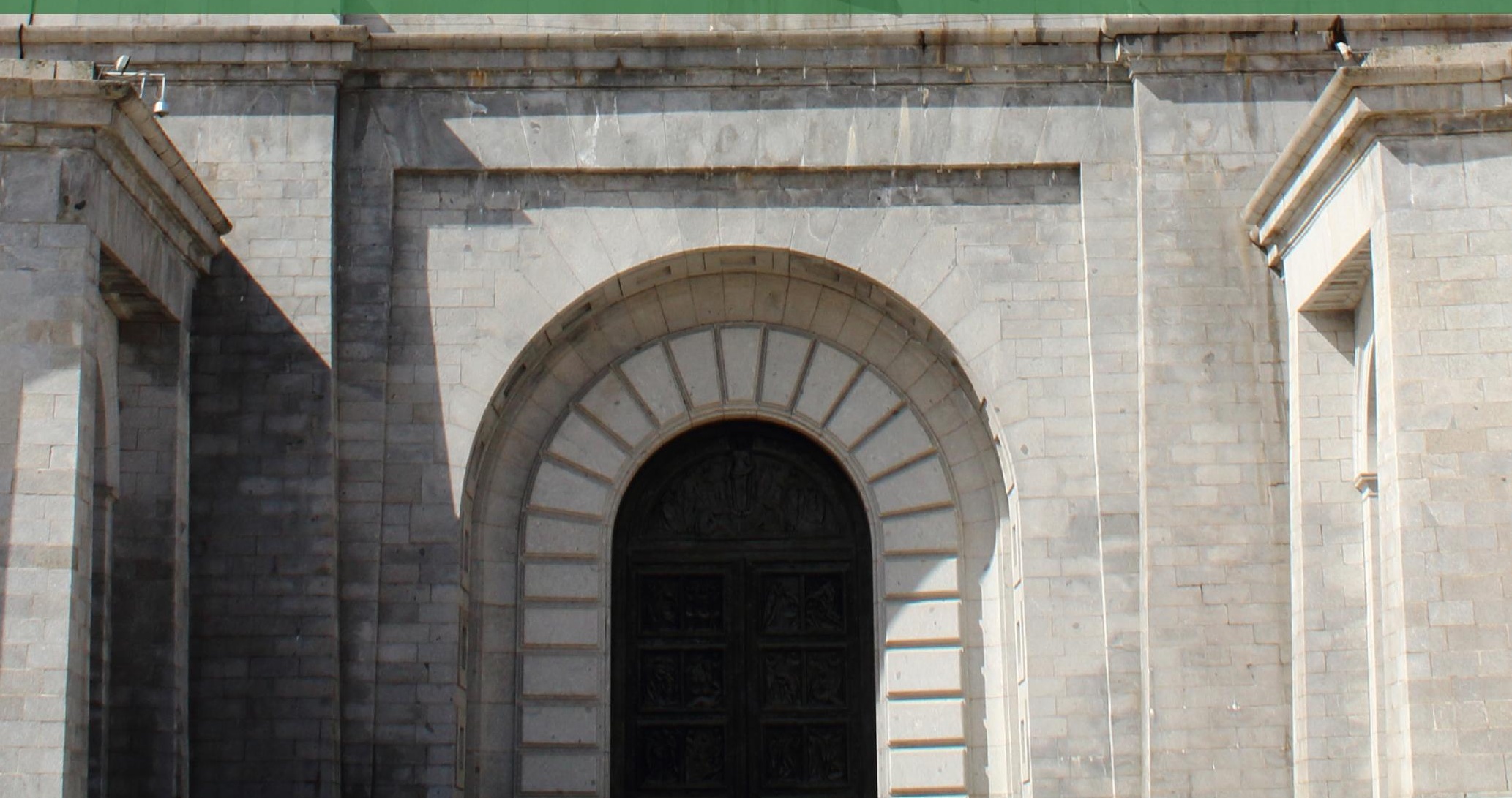




\section{Panta Rei \\ Revista Digital de Ciencia \\ y Didáctica de la Historia}

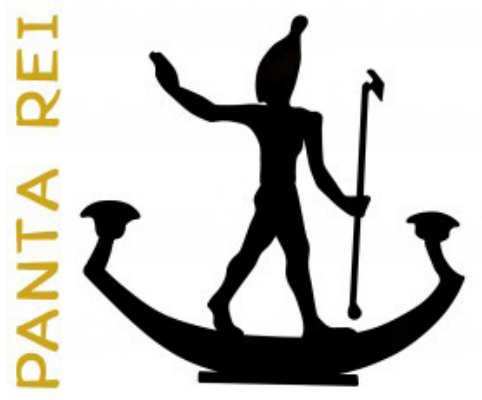

\section{8}

Revista anual

Fecha de inicio: 1995

Revista Panta Rei. pantarei@um.es

Edita:

Centro de Estudios del Próximo Oriente y la Antigüedad Tardía - CEPOAT

Edificio Universitario Saavedra Fajardo.

Universidad de Murcia

C/ Actor Isidoro Máiquez, 9

30007 - MURCIA - ESPAÑA

Teléfono: (+34) 868883890

cepoat@um.es

Web: www.um.es/cepoat/pantarei

Edición 2018

ISSNe: 2386-8864

ISSN: 1136-2464

Depósito legal: MU-966-1995

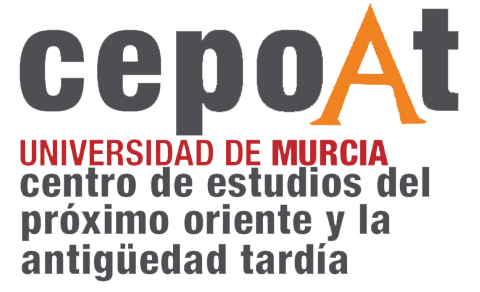

En Portada: Valle de los Caídos, Madrid. (Fotografía de: Adrián Rosell Lucas).

Responsables de los textos: Sus autores.

Responsable de la presente edición: Consejo Editorial Panta Rei. 


\section{CONSEJO DE REDACCIÓN}

\section{Coordinador editorial}

Egea Vivancos, Alejandro

[Didáctica de las Ciencias Sociales, UMU]

\section{Editores}

Botí Hernández, Juan Jesús

[CEPOAT, UMU]

Jiménez Vialás, Helena

[UMU]

López Muñoz, Damaris

[UJA]

Meseguer Gil, Antonio José

[CEPOAT, UNED]

Sáez Giménez, David Omar

[CEPOAT, UMU]

Sánchez Mondéjar, Celso Miguel

[Patrimonio Inteligente]

\section{Secretaria}

Arias Ferrer, Laura

[Didáctica de las Ciencias Sociales, UMU]

\section{Responsable informático}

Martínez García, José Javier

[CEPOAT, UMU]

\section{Traducción y corrección lingüística}

Martínez Martínez, Cristina

[Sociedad Española de Lenguas Modernas]

Albaladejo Albaladejo, Sara

[ISEN, UMU]

\section{CONSEJO ASESOR}

Adroher Auroux, Andrés María [Arqueología, Universidad de Granada]

Albero Muñoz, $\mathrm{M}^{\mathrm{a}}$ del Mar $\left[\mathrm{H} .^{\mathrm{a}}\right.$ del Arte, Universidad de Murcia]

Alia Miranda, Francisco [Historia Contemporánea, UCLM]

Arciniega García, Luis [Historia del Arte, Universidad de Valencia]
Barrio Barrio, Juan Antonio [Historia Medieval, Universidad de Alicante]

Castellano i Solé, Núria [Egiptología, Schola Didàctica Activa S.L.]

Chapman, Arthur [History Education, University College of London, Reino Unido]

Cid López, Rosa María [Historia Antigua, Universidad de Oviedo]

Cobacho López, Ángel [Derecho, Universidad de Murcia]

Cuenca López, José María [Didáctica de las Ciencias Sociales, Universidad de Huelva]

Egea Bruno, Pedro $\mathrm{M}^{\mathrm{a}}$ [Historia Contemporánea, Universidad de Murcia]

Feijoo Martínez, Santiago [Arqueología, Consorcio Ciudad Monumental de Mérida]

García Atienzar, Gabriel [Prehistoria, Universidad de Alicante]

Ginestí Rosell, Anna [Filología Clásica, Katholische Universität Eichstätt-Ingolstadt]

González Monfort, Neus [Didáctica de las Ciencias Sociales, Universidad Autónoma de Barcelona]

González Soutelo, Silvia [Arqueología, Universidad de Vigo]

Haber Uriarte, María [Prehistoria, Universidad de Murcia]

Hernández de la Fuente, David [Historia Antigua, Universidad Complutense]

Hutson, Scott R. [Anthropology, University of Kentucky, EEUU]

Igual Luis, David [Historia Medieval, UCLM]

Irigoyen López, Antonio [Historia Moderna, Universidad de Murcia]

Jover Maestre, Francisco Javier [Prehistoria, Universidad de Alicante]

Mahony, Simon [Digital Humanities, University College of London, Reino Unido]

Marsilla de Pascual, Francisco Reyes [Técnicas historiográficas, Universidad de Murcia]

Martínez-Burgos García, Palma [H. ${ }^{\text {a }}$ del Arte, UCLM]

Mathis, Christian [Didaktik der Geschichte, PH Zürich]

Miralles Maldonado, José Carlos [Filología Clásica, Universidad de Murcia]

Molina Gómez, José Antonio [Historia Antigua, Universidad de Murcia]

Mónica Ghirardi [Historia Moderna, Universidad Nacional de Córdoba, Argentina]

Navarro Espinach, Germán [Historia Medieval, Universidad de Zaragoza]

Noguera Celdrán, José Miguel [Arqueología, Universidad de Murcia]

Ortiz Heras, Manuel [Historia Contemporánea, UCLM]

Panzram, Sabine [Historia Antigua, Universität Hamburg]

Pérez Molina, Miguel Emilio [Filología Clásica, Universidad de Murcia]

Prados Martínez, Fernando [Arqueología, Universidad de Alicante]

Sánchez Ibáñez, Raquel [Didáctica de las Ciencias Sociales, Universidad de Murcia]

Sancho Gómez, Miguel Pablo [Educación, UCAM]

Victoria Moreno, Diego [Historia Contemporánea, UNED]

Vilar García, María José [Historia Contemporánea, Universidad de Murcia]

Vivas Sainz, Inmaculada [H. ${ }^{\text {a }}$ del Arte, UNED]

Zamora López, José Ángel [Próximo Oriente Antiguo, CCHS-CSIC] 

Artículos

El estilo decorativo en las primeras producciones cerámicas en el valle del río Vinalopó (Alicante).

Silvia Martínez Amorós.

Límites históricos del Ateísmo: increencia en la Grecia Antigua.

Ramón Soneira Martínez. .33

Dynamics of Power: an Architectural Reading of the Concentration of Power (Ullastret, 4th-3rd Century BC).

David Jesús Cebrián Martínez.

La mujer como exemplum. Subversión, desafío y resistencia en Valerio Máximo.

Lidia González Estrada.

The narrative framing of violence in teaching resources about the Spanish Conquest of America.

Ángela Bermúdez Vélez y Diego Argumero Martínez.

Modelos de conciencia histórica en el alumnado de Educación Secundaria: tradición, simbología y contextualización en torno a los restos del franquismo.

Diego Miguel-Revilla y María Sánchez Agustí.

La importancia de la contextualización curricular en la enseñanza de la Historia en México.

Enrique Bautista Rojas.

Experiencia didáctica para la enseñanza de la historia contemporánea a través de las fuentes en Educación Superior.

Nayra Llonch-Molina y Verónica Parisi-Moreno 161

\section{Reseñas}

Prados, F., Jiménez, H., Martínez, J.J. (Eds.) (2017). Menorca entre fenicis i púnics / Menorca entre fenicios y púnicos. Murcia: Centro de Estudios del Próximo Oriente y la Antigüedad Tardía de la Universidad de Murcia. 320 págs.

Pete Missingham

Bravo Bosch, M. J. (2017). Mujeres y símbolos en la Roma Republicana. Análisis jurídico-histórico de Lucrecia y Cornelia. Madrid: Dykinson. 333 págs.

Borja Méndez Santiago.

Karp, M. (2016). This Vast Southern Empire: Slaveholders at the Helm of American Foreign Policy. Cambridge: Harvard University Press. 360 pages.

Kevin Caprice.

Livi-Bacci, Massimo (2012). A Short History of Migration. Cambridge: Polity Press. 157 pages.

Alejandro Salamanca Rodríguez. 189

Normas de publicación/Publishing rules 



\title{
Límites históricos del Ateísmo: increencia en la Grecia Antigua
}

\author{
Historical limits of Atheism: Disbelief in the Ancient Greece
}

\author{
Soneira Martínez, Ramón ${ }^{1}$ \\ Universidad Complutense de Madrid
}

Recibido: 30/01/2017

Aceptado: 09/02/2018

Para citar este artículo: Soneira Martínez, Ramón (2018). Límites históricos del Ateísmo: increencia en la Grecia Antigua. Panta Rei. Revista Digital de Ciencia y Didáctica de la Historia, 33-49.

ISSNe: $2386-8864$

DOI: $10.6018 /$ pantarei/2018/2

\section{Resumen}

El presente artículo presenta una discusión histórica en torno a los límites conceptuales e históricos del fenómeno irreligioso del ateísmo. Se busca presentar las líneas metodológicas del estudio del ateísmo y proyectarlas en el contexto histórico, cultural y religioso de la Grecia Antigua. Se analizarán las características formales de la religión griega para comprender la existencia de posiciones filosóficas que defendían una postura escéptica sobre los dioses. Se realizará una exposición de las fuentes históricas que nos han permitido analizar estas posturas ateas, desde el inicio de la filosofía con los autores presocráticos hasta el desarrollo de la obra de Platón, cubriendo así un amplio periodo histórico cargado de acontecimientos y complejidad cultural, entre ellos el fenómeno de la increencia.

\section{Palabras clave}

Religión, creencias, civilización griega, historia de las religiones, postmodernidad.

\section{Abstract}

This article presents a historical discussion about the conceptual and historical limits of the irreligious phenomenon of atheism. The main aim is to approach the methodological lines of the study of atheism and to project them in the historical, cultural and religious context of Ancient Greece. The formal characteristics of the Greek religion will be analysed to understand the existence of sceptical positions about the existence of the gods. The study of the different historical sources allows us to analyse these atheistic positions, from the beginning of the philosophy with the presocratic philosophers until the classical period with Plato. It is a huge historical period with complex cultural events like the phenomenon of disbelief.

\section{Keywords}

Religion, beliefs, Greek civilization, religious studies, postmodernism.

1 Para contactar con el autor: Ramón Soneira Martínez. Universidad Complutense de Madrid. rsoneira@ucm. es. 


\section{Introducción}

Los últimos estudios sobre religiones y religiosidad están colocando en el punto de mira los límites conceptuales del termino religión y, por ende, qué aspectos pueden considerarse religiosos o no. En diferentes disciplinas, desde la psicología hasta la sociología, se están replanteando los límites de lo religioso mediante el análisis de conceptos como "irreligiosidad" o "increencia". Cada vez hay un mayor interés por conocer los fenómenos pertenecientes al desapego religioso, no solo en nuestros días, sino también en tiempos pretéritos.

Históricamente, se ha asociado el inicio del ateísmo y el cuestionamiento de la religión en los inicios de la Modernidad, en la llustración, con los grandes pensadores de la llustración Francesa como Diderot, considerado el primer ateo por autores como M. J. Buckley (1987). Pensadores posteriores, sobre todo la llamada izquierda hegeliana, utilizaron el ateísmo como una ideología compatible y necesaria con las ideas que se forjaban bajo los conceptos revolucionarios decimonónicos. Dentro de esa izquierda hegeliana destacan dos pensadores: por un lado K. Marx y por otro L. Feuerbach. Ambos autores originan la crítica más radical hacia el teísmo cristiano que sirve de base para lo que a día de hoy conocemos como ateísmo moderno, cuyo origen, tal y como afirma G. Hyman (2010), no es otro que la propia teología cristiana y su evolución a lo largo de la historia.

Sin embargo, el ateísmo debe entenderse como un fenómeno histórico y por tanto sujeto a sus límites contextuales, de tiempo y espacio. Ha habido posiciones contrarias a investigar el ateísmo en la Antigüedad, ya que se consideraba que la afirmación de ateísmo en la historia antigua escondía en realidad una postura anacrónica flagrante. Sin embargo, si repensamos el propio concepto de ateísmo, veremos que no es algo tan simple. El término "ateo" ha evolucionado incluso dentro de la propia modernidad. Se ha desgranado en diferentes definiciones y divisiones que han generado un cambio importante en el propio concepto, y con ello, cambios en los límites históricos del término. Conceptos como "religiones ateas" son ya utilizadas por los historiadores de las religiones. Destaca, por ejemplo, el "ateísmo del budismo" al que se refiere Díez de Velasco (2014, p. 177)2.

A día de hoy, no se discute que el término "divinidad" o "religiosidad" se desarrolla adscrito a su contexto religioso y cultural y que por tanto lo religioso o divino en la cultura azteca poco tiene que ver con la griega, e incluso ambos conceptos no son lo mismo en el contexto griego y en el romano, a pesar de la visión unitaria de la historiografía clásica. Partiendo de esa base, las posiciones ateas o irreligiosas no pueden ser las mismas en contextos culturales diferentes. Así, el concepto de ateísmo toma sus limitaciones conceptuales del contexto histórico y cultural en el cual se desarrolla, en su propio tiempo y espacio. Para entender y analizar esta premisa analizaremos la coyuntura de la Grecia Antigua con el objetivo de desarrollar cómo el ateísmo puede ser estudiado en contextos pasados eliminando la visión occidental y moderna del ateísmo contemporáneo. No se trata de defender las posiciones ateas o dotar de mayor argumentación la defensa de la inexistencia de lo divino, sino de entender que en el contexto griego existían posturas ateas. Para ello nuestra primera labor es definir el concepto que vamos a desarrollar de ateísmo.

\section{Concepto de ateísmo}

El ateísmo ha tenido una gran variedad de definiciones así como de connotaciones diversas. El concepto "ateo" nace de la etimología griega mediante la unión de la a- privativa y theos, dios, sin embargo, esta es simplemente una definición etimológica. El término ha desarrollado diferentes connotaciones y significados a lo largo de la historia e incluso una tipología diversa en relación a las distintas posturas ateas.

2 Existe toda una reflexión sobre la compatibilidad entre el ateísmo y la religiosidad en autores como G. Puente Ojea (1997), R. Panikkar (1997), V. Merlo (2007), G. Bueno (2007), A. Comte-Sponville (2008), A. Pániker (2011), S. Pániker (2014) entre otros muchos. Una síntesis de toda esta reflexión puede apreciarse en el trabajo de A. Ramos González (2016). 
Para definir y limitar a qué nos referimos cuando hablamos de ateísmo debemos incidir, precisamente, en esa tipología dentro de las posturas ateas. Para simplificar la concepción del término, hablaremos de dos divisiones diferentes. Una división de naturaleza y otra de contexto. La primera tiene que ver con la naturaleza de la postura atea, hablaremos de un ateísmo negativo frente a un ateísmo positivo. La segunda división se relaciona, no tanto con la propia naturaleza de la postura atea, sino con el contexto religioso en el que se define dicha postura, de modo que hablaremos de ateísmo estricto frente a un ateísmo amplio.

En cuanto a la división de naturaleza, el ateísmo negativo se define como la postura de negación de lo divino. Se niega la existencia de los dioses, es el termino ateo desde una perspectiva estrictamente etimológica, la partícula de negación y la palabra theos. Sin embargo, el ateísmo positivo va más allá, y trata de argumentar a favor de la inexistencia. No solo niega la existencia divina, sino que además trata de defender la imposibilidad de la existencia, como defiende $\mathrm{M}$. Martin (2010). Este tipo de ateísmo es el que se ha desarrollado en la modernidad y ha llegado a nuestros días con mayor vigencia. Aquella izquierda hegeliana lo pondrá en práctica para afirmar la necesidad de dejar la religión a un lado.

En una segunda división referida al contexto, las posturas ateas pueden ser estrictas o amplias. El ateísmo amplio es aquel que niega cualquier tipo de divinidad sea del contexto que fuere. Un ateo amplio sería aquella persona que negaría tanto la existencia del Dios monoteísta omnipotente y omnisciente así como la existencia de los dioses hindúes o aztecas, es decir, niega la existencia de lo divino independientemente de qué naturaleza divina se desarrolle. El ateísmo estricto, sin embargo, es aquel que niega ciertas naturalezas divinas. Es aquí donde se desarrolla el concepto de "religiones ateas". Un ejemplo: un budista de la tradición Theravada es un ateo en un contexto católico, ya que niega la existencia de un Dios omnipotente y omnisciente, sin embargo, a su vez no podría ser ateo amplio ya que cree en un desarrollo espiritual y en el alcance del Nirvana, una posición espiritual ulterior. Esta paradoja se supera bajo el término del ateísmo estricto, un budista sería así una persona atea estricta, pues únicamente es atea en un contexto monoteísta. Así, religiones como el jainismo, el budismo Theravada y el confucianismo han sido estudiadas como "religiones ateas" en sentido estricto por autores como M. Martin (2010).

Partiendo de estas definiciones del concepto de ateísmo podemos estudiar las posiciones ateas en su contexto histórico y cultural y comprobar qué tipo de increencias se desarrollan en otros periodos históricos y religiosos. Existen a día de hoy estudios sobre la irreligiosidad en el Islam, como la obra de S. Stroumsa (1999), o incluso en el judaísmo primitivo como la de J. Gericke (2012). En este artículo nos proponemos utilizar esa diferenciación tipológica de las distintas posturas ateas para buscar la existencia de posiciones irreligiosas en el contexto de la Grecia Antigua.

\section{Características de la religión griega en torno a la increencia}

Tras la publicación de la obra de T. Whitmarsh Battling the Gods: Atheism in the Ancient World en 2015, se ha consolidado un interés cada vez mayor sobre el estudio de las posiciones ateas y la increencia en la religiosidad griega. Autores como J. Bremmer (2010) o D. Sedley (2013) ya habían tratado el estudio de la irreligiosidad en el marco de la Grecia Antigua, pero hasta hoy no se había realizado un estudio específico del ateísmo en el mundo antiguo de manera transversal con una perspectiva histórica y no beligerante. Tampoco se trata de una obra que busque la catalogación de cada una de las fuentes donde aparecen argumentos ateos, pues esa labor ya la realizó M. Winiarczyk (1976) sobre todo con la publicación "Bibliographie zum antiken Atheismus," en 1989, sino más bien analizar el fenómeno del ateísmo desde una posición más general. En este artículo se tratará más el segundo aspecto que la propia catalogación de fuentes ateas en el contexto griego.

La primera pregunta que nos viene a la cabeza es si podemos hablar de ateísmo en la Grecia Antigua. Por un lado, debemos partir de la base que se ha desarrollado en los apartados anteriores. Debemos analizar las posiciones ateas, en este contexto, siempre bajo la posición del ateísmo negativo, tal y como afirma J. Bremmer (2010), es decir, existen posturas que niegan la existencia 
de los dioses o bien ponen en tela de juicio la existencia de las divinidades, pero raramente se encuentran casos en los que se defienda la inexistencia, y si es así, siempre desde un ateísmo estricto en referencia a la religión tradicional griega descrita por los poetas. Estas posiciones pueden observarse en diferentes fuentes y escritos, pero es curioso que comienzan a aparecer a finales del s. V a. C. y sobre todo a inicios del s. IV a. C., coincidiendo con uno de los juicios más famosos de la Antigüedad, el juicio de Sócrates, culpado, entre otros motivos, por ser ateo e introducir nuevos dioses en la ciudad, aunque no puede entenderse sin analizar los inicios de la filosofía y la influencia del pensamiento jonio en Grecia.

Un segundo punto que permite conocer si existían o no las posiciones ateas, o si podemos hablar de ateísmo en la Grecia Antigua, es su contexto religioso. Bajo mi punto de vista, dentro del contexto religioso de la Grecia Antigua hay tres grandes bloques fundamentales que explican la existencia de posturas ateas o irreligiosas: el carácter politeísta de la religión griega, la confluencia de las tres teologías y el papel moral del individuo en el contexto de la polis griega.

\subsection{El politeísmo griego}

Para conocer los limites históricos y el contexto de un fenómeno como el ateísmo y las posiciones irreligiosas en una religión concreta debemos conocer las características del contexto religioso en el que se sitúan dichas posiciones. En este caso, el contexto politeísta griego posee unas características concretas que permitieron la aparición de ciertas posiciones irreligiosas sin crear un conflicto social relevante, al menos hasta finales del s. V a. C. y principios del s. IV a. C.

Analizar el contexto religioso politeísta en el mundo griego, provocaría una extensión innecesaria en este trabajo y más habiendo diferentes estudios sobre esta cuestión como los de W. Burkert (2007), L. Bruit Zaidman y P. Schmitt Pantel (2002) o la obra de J. N. Bremmer (2006). Sin embargo, cabe recordar ciertos aspectos del politeísmo griego sin los cuales no podrían haberse desarrollado posturas ateas en sentido negativo.

En primer lugar, cabe destacar la gran pluralidad de deidades que conforman todo el complejo sistema de divinidades y seres mitológicos de la religión griega. No solo los dioses olímpicos, también las ninfas, los faunos, los ríos, las abstracciones como la Victoria (nike), incluso los diferentes epítetos que poseen los dioses en los distintos lugares del contexto griego. Además, dicho politeísmo, permitía que se pudiera realizar culto a un dios sin tener que renunciar al resto. No hay cultos incompatibles, ni siquiera la participación en los misterios o los cultos báquicos suponía una contradicción con los cultos de la polis. Podemos afirmar, como lo hace Burkert (2007, p. 293), que "no existe un dios celoso" del resto de divinidades, a diferencia de la tradición judeo-cristiana que excluye a otras divinidades que no sean Dios, como se puede apreciar en el Éxodo (20: 3).

Un segundo aspecto a destacar que diferencia la religión griega de la tradición judeocristiana es la falta de dogma. No existen unas escrituras sagradas en las que se definan los pilares fundamentales de la creencia religiosa. Cuando en la tradición historiográfica se preguntaban cómo la religión griega podía ser una religión sin tener unas escrituras que amparasen las creencias religiosas, se trató de buscar unos escritos que fundamentaran las bases religiosas del mundo heleno. Se tomaron las obras de Homero y Hesíodo como las bases escritas de las creencias religiosas. Sin embargo, ni la Teogonía de Hesíodo ni la llíada y la Odisea de Homero, son en ningún caso las bases dogmáticas de las creencias religiosas griegas. Es cierto que su relevancia cultural en el mundo heleno fue básica y qué la visión del ethnos griego se fundamentó en la lengua y en las obras épicas arcaicas de ambos autores, pero nunca la creencia. Esto permitía una mayor libertad a la hora de pensar y definir la naturaleza de los dioses, pues a la falta de dogma hay que añadir la falta de un clero, de una casta sacerdotal. Existían sacerdotes, pero no un saber único para relacionarse con los dioses (Bruit Zaidman y Schmitt Pantel, 2002; Garland, 1990). Esto impedía que un "cuerpo de especialistas religiosos" poseyera "el capital religioso" y por ende monopolizara el culto y la relación entre los individuos y los dioses para mantener su posición dominante frente al resto de la población, utilizando términos del sociólogo francés P. Bourdieu (1971, p. 304), 
un hecho que se nos presenta en contextos religiosos monoteístas como en la tradición judeocristiana. Como afirman Bruit Zaidman y Schmitt Pantel (2002), existía el culto privado y cualquier ciudadano podía realizarlo en su ámbito doméstico sin necesidad de un personal intermediario. Los sacerdotes que existían se consagraban a un dios concreto dotando así de pluralidad, no solo al abanico de divinidades, sino también a los oficios litúrgicos donde el sacrificio y el ritual poseían un importante papel en la religión griega ${ }^{3}$. Autores como W. Burkert (2007), dotan de gran importancia el acto litúrgico del sacrificio. Los sacerdotes eran magistrados políticos y por tanto se entendía la función religiosa como una función política y cívica, tanto la realización de los actos rituales como la asistencia y participación en ellos.

Todo ello demuestra una característica fundamental en la religión griega, "la gran libertad en la creación religiosa de la que se gozaba", como afirma Díez de Velasco (2014, p. 119). La gran diversidad religiosa, tanto a nivel mitológico como a nivel regional, y la falta de un dogma concreto y excluyente provocaron que la religión griega, como la realidad misma, fuera puesta en tela de juicio tras el nacimiento del saber filosófico. En definitiva, se configuró una teología tradicional compuesta por la llamada "teología de los poetas" de Hesíodo y Homero, y la teología cívica que postulaba y controlaba la ritualidad en la polis. Esta teología tradicional se vio enfrentada a una tercera: la teología de los primeros filósofos, la teología natural.

\subsection{La convergencia de las "tres teologías"}

Un segundo bloque fundamental para entender la existencia de posiciones ateas e irreligiosas en el mundo griego es la convergencia entre las llamadas "tres teologías". El autor alemán W. Burkert (2007) explicó el nacimiento de posiciones escépticas hacia los dioses mediante la afirmación de tres teologías distintas que convivían entre sí y permitían que ciertas contradicciones internas en las posiciones religiosas del mundo griego existieran sin conflicto aparente. Dichas contradicciones se basan en los aspectos del orden moral y la proyección mítica de los dioses. Burkert (2007, p. 420) cita el famoso pasaje de Eurípides en su tragedia Heracles en referencia a la diosa Hera: “¿Quién podría dirigir sus súplicas a una diosa de / tal calaña, una diosa que, encelada con Zeus por la / cama de una mujer, destruye a los benefactores de / la Hélade sin que tengan culpa alguna?" (Eur., Her. 1308s.).

A esta pregunta de Eurípides, casi presentando las bases de una teodicea, Burkert (2007) le da solución con la postulación de las tres teologías. Por un lado, existiría la "teología de los poetas" que se compone de los relatos míticos de la tradición literaria griega. Unos relatos que, como veíamos anteriormente, no era necesario creerse, no eran un dogma. Por otro lado, estaría la "teología de la polis", la teología cívica, la cual suponía un deber cívico ya que organizaba el culto y, sobre todo, la praxis religiosa de los actos religiosos. A esta última, y tras el nacimiento de la filosofía, se añade la "teología natural" con la que era posible, según Burkert (2007, p. 330), "tanto el compromiso espiritual como el distanciamiento escéptico". Esta teología natural nace con la filosofía y se debe a "la emancipación del individuo en una civilización marcada por el crecimiento económico", como afirma el propio Burkert (2007, p. 406).

Estas tres teologías crean el marco del pensamiento religioso en el contexto de la religión griega. La interacción de las tres genera cambios relevantes, no solo en la tradición religiosa sino también en cómo se observa la realidad, y por ende en cómo es la relación entre los individuos y los dioses. Cabe recordar que, para los griegos, los dioses no se sitúan en un lugar extramundano, sino que cohabitan con los hombres. Su morada se encuentra en el Olimpo, no en un espacio ulterior, como es el caso del Dios monoteísta. Si la naturaleza del mundo se percibe de manera distinta y por tanto la dinámica del mundo se explica de manera filosófica, la naturaleza de los dioses también

3 Supone de gran interés los estudios realizados sobre la praxis del sacrificio griego y cómo se estructuraba el descuartizamiento de la víctima bajo el manto de la religiosidad griega. Sobre este tema véase el trabajo de F. Notario (2015). 
provoca cierto escepticismo. Estamos en los primeros pasos hacia el ateísmo negativo y estricto y van a ser los primeros filósofos presocráticos los que inicien tal camino. Debido a la intención de este trabajo, no podemos analizar el pensamiento filosófico de cada uno de estos autores. Sin embargo, me gustaría citar algunos fragmentos que reflejan esos inicios de consolidación de la increencia en la teología de la tradición religiosa griega.

Los autores presocráticos tuvieron en común, en el desarrollo de su pensamiento, el analizar la composición del mundo y la dinámica o dinámicas de la realidad que percibimos y observamos. Así, se centrarán en el papel de los elementos naturales y su composición desde el ápeiron, lo indefinido, de Anaximandro, s. VI a. C., hasta la composición atómica de Demócrito en el s. V a. C. pasando por el principio de vapor, aér, de Anaxímenes. Del gran abanico de "teólogos naturales" me gustaría centrarme en dos concretamente, ya que sus reflexiones en torno a la naturaleza de los dioses son realmente interesantes. Por un lado, Jenófanes de Colofón y, por otro, Heráclito.

Jenófanes de Colofón inicia la crítica más directa a la tradición religiosa griega. Jenófanes conocía perfectamente lo que se ha denominado como pensamiento jonio, el origen del pensamiento filosófico. Emigró a Italia desde su localidad natal en Asia Menor tras la conquista de los persas como recoge el autor W. Jaeger (1952). Su teología se caracteriza por una idea de dios como la Unidad inmóvil, inmortal e impasible, rompiendo así con la idea de divinidad que había en la tradición griega en torno a los dioses olímpicos, a los cuales critica con el análisis de dos elementos: el antropomorfismo y la moralidad de los dioses. En torno a este último elemento afirma que los dioses "hacen toda clase de cosas que los hombres consideraría vergonzosas: robar, cometer adulterio y engañarse unos a otros" (DK, 11, B 11/B 12). En referencia a la crítica directa hacia la naturaleza antropomórfica de los dioses, afirma:

Pero si los bueyes, (caballos) y leones tuvieran manos

o pudieran dibujar con ellas y realizar obras como los hombres;

dibujarían los aspectos de los dioses y harían sus cuerpos;

los caballos semejantes a los caballos, los bueyes a bueyes,

tal como si tuvieran la figura correspondiente a cada uno. (DK, 11, B 15)

Y, además, "los etíopes (dicen que sus dioses son) de nariz chata / y negros; los tracios, que (tienen) ojos azules y pelo" (DK, 11, B 16), relativizando el aspecto de los dioses según el grupo humano correspondiente.

Jenófanes manifiesta su crítica más directa a la concepción tradicional de los dioses griegos. Su crítica a la "teología de los poetas" de manera directa no era además un caso aislado como observa W. Jaeger (1952), sino que otros pensadores contemporáneos, defenderán posiciones igual de escépticas y críticas hacia la naturaleza de los dioses.

Entre estos pensadores se encuentra Heráclito, quien critica la literalidad de los poetas y la imagen de los dioses que se presentan en los poemas épicos, pero su crítica es mayor aún, pues también reflexiona sobre el propio culto tradicional. Este autor, que desarrolla su vida en el cambio del s. VI a. C. al siglo V a. C., destaca no solo por su famosa visión de la naturaleza dinámica y en continuo movimiento que nos presenta Platón en su Crátilo (402a), sino también por su visión teológica del hecho religioso. La teología de Heráclito define lo divino como una divinidad que, en su dinamismo continuo, desarrolla una lucha entre contrarios: "día-noche, verano-invierno, guerra-paz, saciedad-hambre" (DK, 12, B 67). Su teología se separa de las divinidades olímpicas y continua la crítica al antropomorfismo que ya adelantaba Jenófanes. Su crítica, como decíamos, no solo está orientada a la naturaleza antropomórfica, sino también a los propios actos religiosos. Hay dos de ellos que critica con más dureza: el culto a las estatuas divinas y la purificación mediante la sangre:

En vano se purifican manchándose con sangre, como si alguien tras sumergirse en el fango se limpiara con fango: parecería haber enloquecido, si alguno de los hombres advirtiera de qué modo obra; y hacen sus plegarias a ídolos, tal como si alguien se pusiera a conversar 
con casas, sin saber que pueden ser dioses ni héroes (DK, 12, B 5)

Se trata de una crítica ya no solo metafísica hacia la naturaleza de los dioses, sino también a ciertas prácticas religiosas que se llevaban a cabo en la religión de la polis. La crítica y la reflexión filosófica ya no se sitúan en el plano únicamente de las ideas, ahora también afectan a las costumbres religiosas. Como define W. Burkert (2007, p. 409), "se ha consumado la ruptura con la tradición", debido a las reflexiones realizadas en torno a la naturaleza y su composición, se ha desembocado en reflexionar no solo en plano abstracto, también en los actos religiosos. Es cierto que aún es un periodo temprano como para que la reflexión de estos autores cambie de alguna forma la praxis religiosa de las comunidades cívicas griegas, pero sienta las bases de un debate en torno a la religión que se desarrollará a lo largo del siglo $\mathrm{V}$ a. C. y que desembocará en el siglo IV a. C. con cambios importantes.

En definitiva, el antropomorfismo, característica descriptiva de la "teología de los poetas", ha demostrado ser incompatible con la "teología natural". Es difícil de creer que los dioses que existen tengan forma humana y actúen como humanos. Esta increencia en el antropomorfismo religioso que se desarrolla en los pensadores presocráticos, no desaparecerá. Se mantendrá en la filosofía griega siglos más tarde. Aun así, continúan las ideas en torno a lo divino como eterno, increado, omnipotente y omnisciente en la búsqueda del origen del mundo. El problema está en que al despersonalizar a los dioses y convertirlos en abstracciones que controlan y manejan la fuerza o fuerzas del mundo mediante unas leyes naturales, se ha transformado la relación entre el individuo y los dioses separando a las divinidades de los mortales. Como apunta el propio Burkert (2007, p. 412): "¿Se puede seguir diciendo que lo divino se ocupa de los hombres, de los hombres particulares? Aquí se abre una herida en la religión práctica que nunca podrá volver a cerrarse".

En resolución al conflicto entre la "teología natural" y la "teología de los poetas" se creará un género literario distinto basado en la hermenéutica de los textos tradicionales de los poetas y en relación con las nuevas lecturas de la phýsis: la Alegoría. Aparecen así rapsodos como Teágenes de Regio, quien en el s.IV a. C., influenciado por esas reflexiones en torno a la naturaleza del mundo y los dioses, describe la batalla ente los dioses de la llíada como un conflicto entre elementos naturales: lo ligero contra lo pesado o lo caliente contra lo frío como señala T. Whitmarsh (2015). Ya en el siglo V a. C., destacan los seguidores de Anaxágoras como Metrodoro de Lámpsaco. Finalmente, cabe destacar a finales del siglo $\mathrm{V}$ a. C. el Papiro de Derveni como otro claro ejemplo de la interpretación de un mito teogónico bajo un prisma filosófico, en este caso relacionado con Orfeo. El autor conocía perfectamente las enseñanzas de los autores presocráticos como Parménides o Empédocles, así como autores más contemporáneos como Anaxágoras, Demócrito o Diógenes de Apolonia ${ }^{4}$. Todo ello demuestra que la religión griega en el siglo $\mathrm{V}$ a. $\mathrm{C}$. sufre una serie de cambios de gran relevancia, entre ellos la concepción del individuo dentro de la normatividad cívica de la polis.

\subsection{El papel moral del individuo en la polis}

Durante el siglo $\mathrm{V}$ a. C. la filosofía griega se presenta como un fenómeno cambiante. Los llamados filósofos presocráticos dejan paso a los llamados sofistas y con ello, los temas de reflexión varían. Entra en juego un tema determinante que se une a esa reflexión sobre la phýsis: la moral en relación a la convivencia de los individuos en la polis. Las reflexiones en torno a este tema, unidas a las anteriores ya citadas que criticaban el antropomorfismo y la moralidad de los dioses, tendrán como resultado las posiciones ateas e irreligiosas más drásticas.

En la religión de los antiguos griegos los dioses no suponían un ejemplo de moralidad para la religión práctica de la polis, es decir, los dioses y sus actividades no eran el fundamento moral de

4 Sobre el estudio y traducción del Papiro de Derveni destaca A. Bernabé (2004).

Panta Rei (2018), 33 - 49 
la polis griega. Sin embargo, sí existe una relación entre moralidad de los individuos y los dioses: el temor hacia ellos. Esta idea de hombre piadoso como temeroso de dios (theoudés) es una idea que se encuentra ya en la Odisea, en definitiva, las personas que son temerosas de los dioses son personas buenas. Se genera así una dialéctica interesante entre la moralidad de los dioses y la moralidad del individuo dentro de la sociedad griega. Dicha dialéctica "entre dioses amorales y moral religiosa", basada en la critica que veíamos anteriormente de Jenófanes a la moralidad de los dioses, queda fijada en el mito en un estadio primitivo que en contradicción "llevó al desarrollo de la cultura y la moral" tal y como defiende Burkert (2007, p. 330) o Whitmarsh (2015), al indicar que era muy difícil tomar como ejemplos morales a los dioses descritos en la Guerra de Troya.

Sin embargo, existe un debate abierto sobre si las leyes cívicas, responsables de lo que se debe hacer y de lo que no, poseen una naturaleza divina, sagrada, o no. Algunos autores, como el propio Whitmarsh (2015), afirman que los griegos sabían separar lo sagrado de lo profano y entendían que las leyes, al no venir de una ley divina como por ejemplo la sharia en el Islam o las leyes recogidas en el Deuteronomio, eran de origen humano y, por ende, profanas, seculares y cuestionables. Así, según este autor, las leyes cívicas no estaban teologizadas, lo que permitía la apertura de un debate en torno a los limites cívicos de la moralidad y las bases de esta en relación a lo sagrado ${ }^{5}$. No es más que una consecuencia religiosa de esa "gran libertad religiosa" que citábamos anteriormente.

Las enseñanzas de los sofistas continuaron esa libertad de pensamiento en torno a los límites de lo divino y de lo moral y, al igual que hicieron ciertos filósofos presocráticos como los citados, también criticaron la religión tradicional griega, como apunta D. F. Leão (2004). Entran en juego dos conceptos que hasta ahora apenas habían tenido relevancia en la historia del pensamiento griego, eusebeia (piedad) y su contrario asébeia (impiedad). Es necesario definir ciertos aspectos en torno a este delito de impiedad, ya que en muchas ocasiones está relacionado con la increencia y el ateísmo. Hay que distinguir claramente la idea de piedad griega de la idea de piedad cristiana que ha llegado a nuestros días. La piedad cristiana se caracteriza por una fuerte devoción hacia la deidad y por tanto una relación constante con Dios. Sin embargo, la noción de piedad en el mundo griego es bastante dispar. En la concepción griega lo excesivo siempre era negativo al igual que la escasez. Por tanto la relación con las divinidades debía realizarse en su justa medida. Así, el exceso de devoción hacia los dioses demostraba una cierta "enfermedad". No se "amaba" a los dioses, solo se les hacia los honores correspondientes, theôn timaí. Su contrario, asébeia, es aún más complicado de determinar. ¿Qué supone un delito de impiedad? Muchos son los autores que han trabajo los aspectos legales de este término y se ha llegado a la conclusión de que en la gran mayoría de los casos los delitos de asébeia están referidos a actos concretos como robar en un templo, profanar los misterios o robar objetos sagrados, entre otras cosas. Autores como D. Cohen (1988) enumeran los casos más usuales. Sin embargo, en el siglo V a. C., sobre todo en la segunda mitad, el delito de asébeia se amplía y ya no afecta únicamente a los "actos impíos", también se castigan ciertos pensamientos o ciertas posturas filosóficas, entre ellas, el ateísmo, o posturas ateas como señala Leão (2004). Es precisamente en el siglo V a. C. cuando nace el término átheos para expresar una postura filosófica que incurre el delito de asébeia suprimiendo la relación con los dioses, y es en Persas de Esquilo donde aparece por primera vez dicha palabra en referencia a la negación de los dioses (Aesch., Pers. 808). Todo ello queda reflejado en el llamado Decreto de Diopites del año 432 a. C. que cita Plutarco (Plu., Per. 32.2) en relación a la acusación de asébeia a Aspasia: "Y Diopites presentó un decreto para que se denunciase a todos aquellos que no creyeran en los dioses o propalaran enseñanzas sobre los fenómenos celestes".

Todo ello cambia drásticamente el panorama de la religión griega. El delito de impiedad ya no es solo el de una persona que realiza acciones consideradas como delito, sino que además no cree en los dioses y enseña la naturaleza de los fenómenos celestes. Aquí el conflicto, ya no es entre la

5 Todo ello desembocará a finales del s. V a. C. y principios del s. IV a. C. en un personaje como Sócrates, el cual se pregunta qué es lo sagrado (hósios), el valor o el bien y que será juzgado por asébeia (impiedad). 
"teología de los poetas" y la "teología natural", va más allá. Es un conflicto entre la "teología natural" y la "teología cívica", es decir, con la praxis religiosa, piadosa, de la polis. Esta relación entre ateo y mal ciudadano va a estar presente incluso en Las Leyes de Platón (PI., Leg. 886a-887b). Platón ya no castiga a aquel que no cumple los actos cultuales correspondientes, sino que castiga el ateísmo filosófico, una manera concreta de entender las divinidades. Es precisamente en los autores del s. $\checkmark$ a. C. en los que se aprecia ese ateísmo teórico y con él, las distintas posturas ateas.

\section{El siglo V a. C. y las posturas ateas}

El siglo V a. C. es uno de los momentos más relevantes de la historia de Grecia. La Grecia clásica ha sido el objeto de estudio en innumerables autores que entendieron este periodo histórico como el zenit de la cultura griega. Ya no solo por los acontecimientos históricos, sino también culturales. En este periodo, Atenas se convierte en el modelo griego clásico que se proyectará en el futuro hasta nuestros días como el modelo de la polis por excelencia. Una polis donde la democracia se había consolidado y se había convertido en uno de los centros de poder más importantes del litoral del mar Mediterráneo.

En este escenario, la religión griega, o al menos el pensamiento filosófico en torno a esta, cambia de manera muy relevante dando lugar a posturas ateas en autores de la época. Los llamados sofistas desarrollan argumentos de un ateísmo filosófico que define las bases de dichas posturas y que, en el caso ateniense, van a convivir en la polis generando ciertos conflictos como el que veíamos anteriormente con el Decreto de Diopites. Para analizar estas posturas vamos a enumerar los casos de este ateísmo filosófico en algunos de los autores más relevantes del periodo.

El primero de ellos, y con el cual se origina este pensamiento ateo filosófico, es Protágoras de Abdera, quien afirmó que "De todas las cosas la medida es el hombre" (D.L., IX, 51). Este autor, a pesar de no ser natural de Atenas, pasó toda su vida allí, en torno al círculo de confianza de Pericles ${ }^{6}$. En este círculo de confianza se encontraban otros autores relevantes como Anaxágoras, el cual fue juzgado por asébeia al afirmar que el sol era una "masa metálica incandescente y mayor que el Peloponeso" (D.L., II, 8). Protágoras fue condenado por asébeia debido a su obra, ya perdida, Sobre los dioses (Plácido Suárez, 1988). En esta obra afirmaba: "Acerca de los dioses no puedo saber ni cómo son ni cómo no son. Porque muchos son los impedimentos para saberlo: la oscuridad del tema y lo breve que es la vida humana" (D.L., IX, 51). Esta obra le provocó el destierro y que su obra fuese quemada en el ágora de Atenas como relata Diógenes Laercio (IX, 52). Como se puede apreciar, se ponen en relación tanto la postura escéptica hacia la realidad natural, postura que ya existía en los filósofos anteriores, con la postura escéptica en torno a los dioses. Dos posturas que quedaban ligadas en el anteriormente citado, Decreto de Diopites. Es cierto que esta reflexión de Protágoras no puede afirmarse como una posición atea, pues no niega la existencia de los dioses. Se trataría pues de un ateísmo débil, más cercano al agnosticismo, como afirma D. Sedley (2013), en el que se desarrolla un relativismo inicial que afecta a la naturaleza de los dioses (Durán López, 2011). Se genera con ello una reflexión en torno a los dioses descritos por los poetas Homero y Hesíodo que aparece en autores contemporáneos como Heródoto (Hdt., II, 53). Al poner en tela de juicio la naturaleza de las divinidades en el escrito de Protágoras, se asentaron las bases para las futuras posturas ateas en las que sí se hablará de una inexistencia de los dioses, al menos, tal como se concebían tradicionalmente las divinidades griegas. Sobre todo, bajo la postura de que los dioses antropomorfos descritos por los poetas son una invención humana, lo que denota un ateísmo negativo y además estricto hacia esa religión griega tradicional, a esa "teología de los poetas".

Un segundo autor destacable es Pródico de Ceos. Este autor da un paso más allá y define que los dioses de la teología de los poetas, objeto de la creencia popular, no existen. Son relatos creados por los seres humanos que divinizaron la naturaleza, los reyes y los fenómenos celestes

6 En torno al estudio del círculo de amistades de Pericles y los delitos de asébeia destaca J. A. García González (2001). 
así como los elementos que necesitaban de la naturaleza como el agua, el grano o el vino y a cada uno de ellos le atribuyeron una divinidad, dando lugar así al panteón politeísta. Así, para Pródico, había una etapa primitiva, sin dioses, que dio lugar a la civilización mediante la agricultura y esta, a la construcción religiosa politeísta. Asocia por ejemplo el culto de Deméter con la producción del pan y el de Dioniso al cultivo vinícola. Toda esta postura filosófica seguramente fue recogida en su obra Horai o Las Horas, una obra que nos ha llegado muy fragmentada. Esta postura filosófica no pasó desapercibida pues fue criticada en obras teatrales como Los pájaros de Aristófanes o Las Bacantes de Eurípides. Demócrito continuó las tesis de Pródico, pero introduciendo el factor miedo, el temor hacia los fenómenos celestes como origen de la religión. Así, bajo el generó de la alegoría, afirma que los seres humanos llamaron a la "morada del Aire" el lugar donde habita Zeus (DK 55, B 30). Demócrito defiende así una teoría sociológica concreta en torno al origen de la religión atribuyéndole el origen de la religión a una visión primitiva del mundo natural. W. Jaeger (1952) señala que, con Demócrito, los filósofos se separan de la cultura de la población constituyendo su categoría de sabios, de filósofos.

La idea de que los dioses son una invención humana persiste en esta etapa, y autores como Critias dan continuidad de ello. De hecho, el fragmento de la obra teatral Sísifo (DK, 81, B 25), atribuida a Critias $^{7}$, define perfectamente esa reflexión en torno a la inventiva religiosa por parte del ser humano. En este texto se continua con la idea irreligiosa que define la religión como una invención de los hombres debido al miedo, como Demócrito, pero se le añade una parte fundamental: las leyes cívicas. En el texto se justifica la creación, ya no solo de los dioses homéricos, sino del concepto de divinidad como extensión de las leyes cívicas, las cuales nacen del ser humano. Esta invención tiene como fin crear un castigo para aquellas personas que no cumplen la ley de manera oculta y así que tal violación de las leyes no escapara de "la atención de los dioses". La introducción del nómos como uno de los factores originarios de la creación de la religión, o de la idea de lo divino, es un paso importantísimo en la crítica de la tradición religiosa y, con ello, en la fundamentación de la increencia. Pues si el pensamiento filosófico en torno a la phýsis introdujo los factores naturales como origen de la religiosidad y por ende fueron puestos en tela de juicio, ahora lo que se presenta como origen de la religiosidad es la propia convivencia cívica, las leyes. Una segunda idea fundamental, y que diferencia este testimonio del resto, es que su posición ante el origen y la naturaleza de la divinidad ya no es en oposición a los dioses olímpicos o a la tradición de los poetas, sino que es una posición crítica a la propia idea abstracta de lo divino. No se está únicamente negando la existencia de los dioses antropomorfos, sino que se está afirmando que la propia idea de lo divino, que la religión, es un constructo humano. Esto provoca que ya no hablemos de un agnosticismo o ateísmo débil como el de Protágoras, ni siquiera de un ateísmo estricto en relación a la teología tradicional de los poetas, en este caso, estamos ante lo que algunos autores como D. Sedley (2013) afirman que puede ser incluso un ateísmo positivo. Critias se convierte así en un claro ejemplo del ateísmo griego, es el resultado del devenir filosófico que se ha ido analizando anteriormente. Además, no hay que olvidar que se trata de una obra teatral y no simplemente un ensayo. Por lo tanto, que una obra así fuese representada indica, como afirma J. N. Bremmer (2010), que la población conocía al menos esta argumentación filosófica aunque fuera de una manera negativa, es decir, una burla. Lo fragmentada que ha llegado esta obra imposibilita saber la intencionalidad del texto, pero eso no elimina que se conocieran tales argumentos irreligiosos en la sociedad griega, al menos en la polis ateniense.

En definitiva, este texto nos presenta una realidad dentro de la religiosidad griega. La percepción ante lo religioso ha cambiado en gran medida y es por ello por lo que aparecerán otros autores que, al igual que Critias, demuestren esa relatividad de la afirmación de lo divino. Como afirma W. Burkert (2007, p. 417): "Con Protágoras, Pródico y Critias aparece el ateísmo, al menos

7 La autoría del fragmento de Sísifo ha sido discutida. Algunos autores han defendido que el autor era Eurípides mientras que otros apuestan por Critias. En este caso utilizo la postura defendida por W. Burkert (2007). 
como posibilidad y, aunque no se exprese directamente, no se puede pasar por alto ni excluir". Esta reflexión tan inusual en torno a lo divino no es más que una respuesta a los acontecimientos históricos que se desarrollaron en esta etapa.

En el año 430 a. C., contemporáneo al Decreto de Diopites, la peste asola Atenas y esto genera no solo una crisis social sino también religiosa. Personas que eran devotas y buenas murieron a causa de la peste, mientras que personas impías y malvadas seguían viviendo sin ningún problema, tal y como nos lo cuenta Tucídides: "Ningún temor de los dioses ni ley humana los detenía; de una parte juzgaban que daba lo mismo honrar o no honrar a los dioses, dado que veían que todo el mundo moría igualmente, y, en cuanto a sus culpas, nadie esperaba vivir hasta el momento de celebrarse el juicio y recibir su merecido" (Th., II, 53,4). Esa especie de "injusticia" divina en la cual aquellos que honran a los dioses mueren y los impíos continúan viviendo es un tema que aparece también en el teatro de la época. El propio Eurípides en su obra Belerofonte, la cual nos ha llegado fragmentada, o incluso en su obra Hipólito cuestiona esa relación entre religión y nómos, pues quienes son buenos son castigados con desgracias y los malvados continúan ejerciendo sus malas costumbres (Eur., Hipp., 1325-1341). Se nos presenta aquí uno de los problemas más discutidos en la teodicea religiosa, la justicia divina. Nos recuerda a Job y sus interrogaciones inquisitivas para descubrir el porqué de tal realidad. El propio Aristófanes acusó a Eurípides de ateo por tales reflexiones en Las Tesmoforias en boca de una de las mujeres:

Durante un tiempo, unas veces mejor y otras peor, me iba defendiendo; pero ahora ese tragediero ha logrado convencer a los hombres de que no existen los dioses, con lo que no logro vender ni la mitad. Por eso en este momento os digo y os recomiendo a todas que castiguemos a ese sujeto por muchas razones: salvajes males nos hace, mujeres, ¡como que él mismo se ha criado entre verduras salvajes! (Ar., Th. 448-454)

Todo ello desemboca en el año 415 a. C., aun en plena Guerra del Peloponeso. Ese año supone no solo un giro de acontecimientos importante debido a la famosa Expedición a Sicilia de Alcibíades, también debido a dos actos profanos que se realizan en la ciudad de Atenas. Por un lado, tendrá al propio Alcibíades como protagonista tras ser acusado de profanar los misterios de Eleusis, acusado de asébeia, y por otro, a Andócides y la mutilación de los hermas, las estatuas en honor al dios Hermes, por lo que igualmente fue acusado de asébeia viéndose obligado a exiliarse ${ }^{8}$. Hubo otros casos de asébeia en este periodo aparte de los ya citados, entre ellos el de Diágoras de Melos. Apenas conocemos la vida de este autor salvo por fragmentos narrados por autores como Diógenes Laercio (VI, 59) quien nos cuenta que desprestigió las ofrendas votivas del santuario de Samotracia para la protección de naufragios, e incluso hay autores, como García González (2001), que lo relacionan con la profanación de los misterios de Eleusis de 415 a. C. Esta pluralidad en torno al delito de asébeia demuestra la apertura de los límites jurídicos de este concepto. El Decreto de Diopites supuso que el delito de asébeia ampliara sus fronteras y, en esa ampliación entraron en juego las posturas ateas, las cuales se habían generado mediante una "alianza profana entre sofística y filosofía natural" (Burkert, 2007, p. 418). Diopites, como adivino y gestor de la religión, se enfrentó directamente con Anaxágoras, al cual culpó de asébeia, pues este defendía la postura de la filosofía natural, el sol como material incandescente y no como un dios. El Decreto no es más que una respuesta conservadora hacia esa alianza defendida por los grupos religiosos más conservadores ante la impotencia de ver cómo la tradición religiosa se iba desmoronando poco a poco con las nuevas posiciones filosóficas. Así, personajes de carácter más conservador, como Aristófanes responden a estas nuevas posturas de manera directa, como se aprecia en Las nubes, donde los ateos son finalmente quemados y se restaura el culto a los dioses antiguos (Ar., Nu., 1476-1491). Esto no quiere decir que Aristófanes sea un claro defensor de un ataque directo a

8 Existe cuantiosa bibliografía sobre ambos casos de asébeia y un intenso debate sobre la causalidad de ambos actos, tanto de la mutilación como de la profanación. Sin embargo, me gustaría destacar dos estudios realmente interesantes: Leão (2012) y Verdegem (2001). 
las personas ateas, sino que denota un discurso presente en la sociedad ateniense en el que se realizaba humor denostando las posturas filosóficas de aquellos que relativizaban la naturaleza de los dioses. No hay que olvidar que justo en este momento se produce además uno de los juicios más famosos de la historia de Grecia, el juicio de Sócrates en el año 399 a. C. Sin adentrarnos mucho en su análisis, cabe destacar que fue acusado de asébeia y por ello tuvo que defender su imagen como hombre devoto tras ser acusado de no creer en los dioses por Meleto (PI., Ap., 24b; 26b-26d). A pesar de la causalidad política que hubiera detrás de todos estos juicios por asébeia, el juicio de Sócrates es una de las escenas donde mejor se puede observar las discusiones que había en Atenas en el cambio de siglo en torno a la idea de lo divino y la naturaleza de los dioses. Ese movimiento que se produce entre los sectores más conservadores de la sociedad verá en Sócrates un ejemplo de impiedad, no solo por sus actos sino también por sus enseñanzas. Precisamente el discípulo más famoso de este será el que elimine la relevancia de las posturas ateas. La mayor respuesta de conservadurismo religioso ante el ateísmo filosófico griego lo dará Platón. Tras él, habrá un cambio radical en la forma de entender la religión griega y su teología.

\section{Platón y el ateísmo griego}

Sin desarrollar la filosofía platónica y su proyección metafísica en torno a la ontología divina, es inevitable en un estudio sobre ateísmo antiguo en la Grecia clásica citar a Platón. Este autor desarrolla toda una nueva teología en torno a la religión griega llegando a unificar la filosofía con la propia teología. Es de hecho él quien acuña el termino theologia, hablar de los dioses (PI., R., 379a). La religión con Platón adquiere una naturaleza más trascendental, ya no se centra únicamente en la praxis religiosa, sino también en la concepción de lo divino y la naturaleza de esta. Términos como alma, adquieren un significado mucho más profundo. La realidad y lo divino se unifican dando una gran importancia al pensamiento religioso. Se trata no solo de un cambio de forma hacia el estudio de lo religioso, sino, como indica Burkert (2007, p. 365), de toda una "revolución del lenguaje" en torno a la religión. Esa mezcla de filosofía y religión permite al autor utilizar el formato del mito para introducir sus enseñanzas filosóficas. No hay una ruptura, sino una convergencia entre ambas posturas, pues no son incompatibles.

Platón utiliza esa alianza entre sofística y filosofía natural, sobre todo de la astronomía, para crear su propia visión del mundo. Tendrán además una clara influencia en el pensamiento del filósofo los planteamientos mistéricos, sobre todo de tipo órfico ${ }^{9}$. A todo ello se añade además un pensamiento ético, la idea de lo bello y el bien son las dos ideas perfectas de las cuales emanan el resto, son el inicio y el fin y son los elementos que definen a la divinidad de Platón.

La obra más interesante para comprender la postura de Platón en torno al ateísmo es Las Leyes. En esta obra se unifican todos estos aspectos, tanto el cívico o ético, como el religioso y el filosófico. En esta obra, hay una lucha constante contra las posturas ateas las cuales son observadas como malas como un hecho a ser perseguido por el Estado. El Estado que nos presenta Platón en Leyes, es muy distinto al que nos describía en La República. En Leyes, nos presenta una "teocracia" (Burkert, 2007, p. 438) donde la religión ejerce un papel imprescindible para el orden cívico y moral: "el dios, ciertamente, ha de ser la medida de todas las cosas; mucho mejor que el hombre, como por ahí suelen decir" (PI., Leg., 716c). En este pasaje se realiza además una clara alusión al sofista Protágoras mostrando ese enfrentamiento entre la visión platónica y la del autor de Abdera.

Para Platón el ateísmo puede darse bajo tres aspectos distintos: aquellos que no creen en "absoluto" en los dioses; aquellos que creen que existen pero que no se preocupan de los mortales y aquellos, "un grupo mayor", "que es el de los peores", que cree que realizando libaciones y sacrificios a los dioses se pueden purgar las malas acciones realizadas en su vida. (PI., Leg., 948c). Son estas personas, no creyentes o mal creyentes, quienes cometen "hecho impío" (PI., Leg., 885b). El ateísmo por tanto va en contra de las leyes del Estado y por ello debe ser castigado y, dependiendo

9 Sobre la relación entre el orfismo y Platón destaca el trabajo de A. Bernabé (2011). 
de si además los ateos cometen actos impuros, el castigo varía. Si se trata de personas ateas pero que son ejemplos cívicos, se les debe dar la oportunidad de volver a entrar en razón con un periodo de cárcel. Se relaciona además la magia con el delito de ateísmo (PI., Leg., 908b-d). El ateísmo es calificado por Platón incluso como una "enfermedad" típica de la juventud (PI., Leg., 888b). Es cierto que, a pesar de todo ello, Platón presenta unas prácticas religiosas que estaban normalizadas en el ámbito de la religión griega como las fiestas o los santuarios, demostrando así que la religión es además un cohesionador social (PI., Leg., 738b, c y d).

Como se puede apreciar, el ateísmo es incompatible con el pensamiento religioso platónico. De alguna forma se elimina el incipiente "grito" de la individualidad que se había ido gestando en el siglo $\mathrm{V}$ a. C. para defender la religión como uno de los factores elementales de la comunidad cívica como apunta W. Burkert (2007). Esa individualidad estallará posteriormente durante el proceso de creación de las escuelas helenísticas, cuando el peso central de las reflexiones filosóficas recaerá en el individuo: la moral, la felicidad, etc. incluso en la pérdida de la pertenencia a una polis por las posiciones apátridas o "apolis" de la escuela cínica. Así, Epicuro afirma que quien sacie su cuerpo competirá "incluso con Zeus en cuestión de felicidad" (Epicur., Sent.Vat., 6, 33).

Platón consigue que nunca más se separe el pensamiento religioso del filosófico, como ocurría tiempo atrás, cuando la "teología natural" se posicionaba frente a la "teología de los poetas" y a la "teología cívica". En este caso pensar metafísica y pensar lo ético esta intrínsecamente relacionado con lo religioso, como se mostrará más adelante en el helenismo.

El ateísmo desaparece como una postura filosófica desconectada de la religión. La tradición histórica ha querido definir a Epicuro como ateo, ya en el siglo IV a. C., sin embargo, Epicuro afirma que los dioses existen pero que la gente cree en unos dioses que no son reales, "no son como el común de las gentes se los imagina" (Epicur., Ep., 4, 123). Es una filosofía que ha dejado de lado una teología centrada en los dioses, la búsqueda religiosa se centra ahora en temas espirituales e individuales. Platón condenó las posturas ateas al olvido y asentó las formas ontológicas de pensar la divinidad, las cuales se expandieron a través del neoplatonismo por Oriente y Occidente y sentaron las bases de la metafísica cristiana y posteriormente de la musulmana. Toda la teología medieval cristiana y musulmana, sobre todo en la Alta Edad Media, tendrá como base los escritos de Platón, y por tanto el ateísmo y las posturas ateas continuarán siendo vistas negativamente a lo largo de la historia. No será hasta los comienzos de la Modernidad cuando el ateísmo resurja con unos parámetros culturales y filosóficos distintos a los expuestos en la Grecia Antigua.

\section{Reflexiones finales}

Para concluir este trabajo, cabe afirmar una serie de cuestiones. Por un lado, en torno al ateísmo y su desarrollo en Grecia y, por otro, en referencia a la apuesta metodológica por el estudio de la increencia y el ateísmo en contextos culturales y religiosos distintos a la Europa moderna.

El ateísmo en sí mismo debe entenderse como un fenómeno histórico que, como tal, posee unas características concretas dependiendo del espacio y el tiempo en los que se desarrolle. Así, el ateísmo debe estudiarse no como una idea universal y verdadera en el pensamiento humano, sino como una reflexión filosófica en torno a un contexto religioso concreto. Hay por tanto que analizar dicho fenómeno y sus características, así como tipologías, para poder realizar un estudio histórico y científico en el contexto cultural que tengamos como objeto de estudio, sea el mundo romano, el cristiano, el budista, etc.

Este trabajo se ha centrado en el estudio de las posiciones ateas en la Grecia Antigua. Se ha demostrado que las posturas ateas y, por tanto, el fenómeno de la irreligiosidad existía en la Grecia Antigua. Esto se debió a los tres factores antes citados, las características del politeísmo griego, la convergencia de las tres teologías y el papel del individuo en el contexto de la polis griega. Estos tres factores posibilitaron la existencia de pensamientos filosóficos que al menos cuestionaran la tradición religiosa griega. Como hemos señalado, se dio en un momento histórico muy peculiar y, debido a la naturaleza de las fuentes que nos han llegado, el fenómeno de la increencia puede 
observarse en el contexto de la polis de Atenas, de la cual poseemos mayor aparato textual. El ateísmo nace en dicho contexto como un ejercicio de duda existencial, una duda que se estaba planteando sobre la realidad natural con el nacimiento de la filosofía. Esa puesta en tela de juicio de la realidad observable suponía un enfrentamiento teológico (entendido como reflexión de la naturaleza de lo divino) con la divinización del mundo que se explicaba a través de la mitología tradicional descrita por los poetas, Homero y Hesíodo principalmente. A su vez, dicha tradición religiosa había construido toda una serie de ritos y prácticas religiosas que poco a poco fueron creando la comunidad cívica de la polis. No son pocos los autores que observan la religión como una base fundamental en el nacimiento de la polis ${ }^{10}$. Cuando las posturas escépticas en torno a la naturaleza comienzan a llegar a las poleis, se genera un conflicto entre la teología tradicional y la nueva forma de entender la naturaleza, que es a su vez una forma religiosa, una teología, pues los filósofos presocráticos no eliminan el concepto de divinidad, sino que se lo atribuyen a otros elementos rechazando la descripción tradicional de las divinidades, algo novedoso, pero no incompatible con la libertad religiosa del politeísmo griego.

Finalmente, y a partir del s. V a. C., las reflexiones escépticas sobre los dioses ya no afectan solo al orden natural, sino también al orden moral. Los inicios de pensamiento en torno a la teodicea de las divinidades griegas generan una respuesta escéptica ante la existencia divina que sobrepasa ya la trasformación de la idea de lo divino en torno al politeísmo y se llega incluso a negar la naturaleza abstracta de lo propiamente divino. La idea abstracta de lo divino se define ahora como un constructo humano, como hemos apreciado en el fragmento de la obra Sísifo atribuida a Critias. Aun así, es una postura minoritaria que deja atrás el ateísmo débil, negativo, casi agnóstico, de los autores anteriores y se acerca más al ateísmo positivo dotando de argumentos a la inexistencia de lo divino y apostando por el intelecto humano como origen de los dioses. Todas esas reflexiones contrarias a la tradición religiosa griega desembocan en una crisis religiosa en la polis de Atenas que coincide con los peores momentos de la polis ateniense en la Guerra del Peloponeso: peste de 430 a. C. y las consecuencias de la Expedición a Sicilia en el año 415 a. C. En esa horquilla de tiempo, la religiosidad cambia y se produce una reacción de los poderes religiosos conservadores ante las posturas ateas. El Decreto de Diopites del 432 a. C. es un claro ejemplo de ello. Es con la llegada de Platón cuando la "revolución" religiosa conservadora llega a su mayor expresión. No solo ataca frontalmente las posturas ateas, tal y como hemos visto en Leyes, sino que además destruye la vía del ateísmo filosófico unificando el desarrollo de la teología con el devenir filosófico. Tanto es así que si se niega lo divino se está negando la propia realidad, los astros y la dinámica natural del mundo. Toda persona que hace filosofía después de Platón no puede no hablar del concepto de lo divino, del origen de la religiosidad. Ese pensamiento platónico, en cuyo sacrificio por unificar filosofía y religión apuesta por un pensamiento más trascendente y alejado de lo empírico, permeará la teología cristiana a través del neoplatonismo, y así cualquier escrito sobre teología cristiana (y más tarde musulmana) no podrá realizar ningún tipo de reflexión sin tener como referencia de autoridad a Platón y con ello la denostada imagen que el autor ateniense proyecta sobre el ateísmo. Habrá que esperar a la Modernidad para que de nuevo aparezcan las dudas en torno a la existencia de la divinidad y será la propia teología cristiana la que provoque el nacimiento de las modernas posturas ateas.

En el mundo griego no se darán apenas casos de ateísmo positivo, pero sí negativo. Es decir, sí que se pondrá en tela de juicio la existencia de los dioses de la tradición épica. Además, habría que hablar de un ateísmo estricto, es decir, las posturas ateas se ven enfrentadas al paradigma religioso de la tradición politeísta griega. Así, aunque algunos autores nieguen la existencia de los dioses olímpicos y mantengan la idea de lo divino y reflexionen en torno a la divinidad, demuestran posturas ateas estrictas hacia la teología de los poetas. No existe en el mundo griego el ateísmo amplio, la negación de cualquier tipo de trascendencia, únicamente y muy alejadamente en el Sísifo,

10 Sobre el nacimiento de la polis y su relación con las practicas cultuales destaca la obra de F. Polignac (1995) y de M. Valdés Guía (2012). 
pero no queda claro y no conocemos su intencionalidad final. Por tanto, el ateísmo en Grecia no es anacrónico sino una realidad. Podemos afirmar que en Grecia existieron posturas ateas estrictas y negativas claramente diversas a las creencias tradicionales de la religión griega. En este caso, los límites históricos del ateísmo se traducen en casos de increencia e irreligiosidad en la Grecia Antigua.

\section{Abreviaturas}

DK. Diels, H. y Kranz, W. Die Fragmente der Vorsokratiker. Berlín. 1903.

\section{Bibliografía}

Bernabé, A. (2004). Textos órficos y filosofía presocrática. Materiales para una comparación. Madrid: Trotta.

Bernabé, A. (2011). Platón y el orfismo - Diálogos entre religión y filosofía. Madrid: Abada Editores.

Bourdieu, P. (1971). Genèse et structure du champ religieux. Revue Française de Sociologie, 12 (3), 295-334.

Bremmer, J. N. (2006) La religión griega. Dioses y hombres, santuarios, rituales y mitos. Córdoba: Ed. El Almendro (ed. original de 1999).

Bremmer, J. N. (2010). El Ateísmo en la Antigüedad. En M. Martin (Ed.), Introducción al ateísmo (pp. 29-44). Madrid: Akal.

Bruit Zaidman, L. y Schmitt Pantel, P. (2002). La religión griega en la polis de la época clásica. Madrid: Akal.

Buckley, M. J. (1987). At the Origins of Modern Atheism. New Haven: Yale University Press.

Bueno, G. (2007). La fe del ateo. Las verdaderas razones del enfrentamiento de la Iglesia con el Gobierno socialista. Madrid: Temas de Hoy.

Burkert, W. (2007). Religión Griega. Arcaica y Clásica. Madrid: Abada Editores (ed. original de 1977).

Cohen, D. (1988). The prosecution of impiety in Athenian law. Zeitschrift der Savigny-Stiftung für Rechtsgeschichte. Romanistische Abteilung, 105 (1), 695-701.

Comte-Sponville, A. (2008) El alma del ateísmo: introducción a una espiritualidad sin Dios. Barcelona: Paidós.

Díez de Velasco, F. P. (2014). Breve historia de las religiones. Madrid: Alianza Editorial (ed. original de 2006).

Durán López, M. A. (2011). Los dioses en crisis. Actitud de los sofistas ante la tendencia religiosa del hombre. Madrid: Ediciones Clásicas.

García González, J. A. (2001). El Silencio Herodoteo y los procesos de asébeia en época de Pericles. Baetica. Estudios de Arte, Geografía e Historia, 23, 425-442.

Garland, R. (1990). Priest and Power in Classical Athens. En M. Beard y J. North (Eds.) Pagan Priests: Religion and Power in the ancient World (pp. 75-91). London: Duckworth.

Gericke, J. (2012). A fourth paradigm? Some thoughts on atheism in Old Testament scholarship. Old Testament Essays, 25 (3), 518-533.

Hyman, G. (2010). El Ateísmo en la Historia Moderna. En M. Martin. (Ed.), Introducción al ateísmo (pp. 45-64). Madrid: Akal.

Jaeger, W. (1952). La teología de los primeros filósofos griegos. México: Fondo de Cultura Económica (ed. original de 1936).

Leão, D. F. (2004). Matéria religiosa: processos de impiedade (asébeia). En D. F. Leão, L. Rossetti y M. G. Z. Fialho (Eds.), Nomos. Direito e sociedade na Antiguidade Clássica / Derecho y sociedad en la Antigüedad Clásica (pp. 201-226). Coimbra-Madrid: Imprensa da Universidade de Coimbra-Ediciones Clásicas.

Leão D. F. (2012). The Eleusinian Mysteries and Political Timing in the Life of Alcibiades. En L. Roig Lanzillotta e I. Muñoz Gallarte (Eds.). Plutarch in the Religious and Philosophical Discourse of 
Late Antiquity (pp. 181-192). Brill: Boston.

Martin, M. (2010). Ateísmo y Religión. En M. Martin (Ed.). Introducción al ateísmo (pp. 245-261). Madrid: Akal.

Merlo, V. (2007). La llamada (de la) Nueva Era: hacia una espiritualidad místico-esotérica. Barcelona: Kairós.

Notario, F. (2015). Despedazando el sacrificio: lo comible, lo incomible y el descuartizamiento de la víctima sacrificial en el mundo griego. En F. J. García, F. Lozano y A. Pereira (Coords.), El alimento de los dioses. Sacrificio y consumo de alimentos en las religiones antiguas. Sevilla: Universidad de Sevilla.

Pániker, A. (2011). El sueño de Shitala, viaje al mundo de las religiones. Barcelona: Kairós.

Pániker, S. (2014). Diario de Otoño. Barcelona: Random House.

Panikkar, R. (1997). El silencio del Buddha. Una introducción al ateísmo religioso. Madrid: Siruela.

Plácido Suárez, D. (1988). La condena de Protágoras en la historia de Atenas. Gerión. Revista de Historia Antigua, 6, 21-37.

Polignac, F. (1995). Cult, Territories and the Origins of the Greek City-State. Chicago: University of Chicago Press.

Puente Ojea, G. (1997). Ateísmo y Religiosidad. Reflexiones sobre un debate. Madrid: Siglo XXI.

Ramos González, A. (2016). Ateísmo y espiritualidad. 'Ilu. Revista de Ciencias de las Religiones, 21, 165-183.

Sedley, D. (2013). From the pre-socratics to the hellenistic age. En S. Bullivant y M. Ruse, M. (Eds.). The Oxford Handbook of Atheism (pp. 139-151). Oxford: Oxford University Press.

Stroumsa, S. (1999). Freethinkers of medieval Islam: Ibn al-Rāwandī, Abū Bakr al-Rāzī, and their impact on Islamic thought. Leiden: Brill.

Valdés Guía, M. (2012). La formación de Atenas. Gestación, nacimiento y desarrollo de una polis (1200/1100 - 600 a. C.). Zaragoza: Pórtico.

Verdegem, S. (2001). On the Road Again: Alcibiade's restoration of the eleusinian pompe in Plu. Alc. 34.3-7. En A. Pérez Jiménez, F. Casadesús Bordoy y Sociedad Española de Plutarquistas (eds.), Estudios sobre Plutarco: misticismo y religiones mistéricas en la obra de Plutarco: Actas del VII Simposio Español sobre Plutarco (Palma de Mallorca, 2-4 de noviembre de 2000) (pp. 451-458). Madrid-Málaga: Ediciones Clásicas-Charta antiqua.

Whitmarsh, T. (2015). Battling the Gods: Atheism in the Ancient World. Nueva York: Alfred A. Knopf. Winiarczyk, M. (1976). Der erste Atheistenkatalog des Kleitomachos. Philologus, 120, 32-46.

Winiarczyk, M. (1989). Bibliographie zum antiken Atheismus. Elenchos, 10, 103-192.

\section{Fuentes}

A.A.V.V. Los filósofos presocráticos / [Jenófanes y Heráclito]. Madrid: Editorial Gredos. 1981. [Edición de Conrado Eggers Lan y Victoria E. Juliá].

Aristófanes. Comedias III. Madrid: Editorial Gredos. 2007. [Edición de Luis M. Macía Aparicio].

Diógenes Laercio. Vidas de los filósofos ilustres. Madrid: Alianza. 2011. [Edición de Carlos García Gual].

Epicuro. Obras Completas. Madrid: Cátedra. 2014. [Edición de José Vara].

Esquilo. Tragedias. Madrid: Editorial Gredos. 1993. [Edición de Bernardo Perea Morales].

Eurípides. Tragedias I. Madrid: Editorial Gredos. 1991. [Edición de Alberto Medina González y Juan Antonio López Férez].

Eurípides. Tragedias II. Madrid: Editorial Gredos. 1985. [Edición de José Luis Calvo Martínez].

Heródoto. Historia. Madrid: Cátedra. 2011. [Edición de Manuel Balasch].

Platón. Diálogos I. Madrid: Editorial Gredos. 1985. [Edición de J. Calonge Ruiz, E. Lledó Íñigo y C. García Gual].

Platón. Diálogos II. Madrid: Editorial Gredos. 1987. [Edición de J. Calonge Ruiz, E. Acosta Méndez, F. J. Olivieri y J. L. Calvo]. 
Platón. Las Leyes. Madrid: Alianza. 2014. [Edición de José Manuel Pabón y Manuel Fernández Galiano].

Plutarco. La Atenas del siglo V. Vidas de Temístocles, Pericles, Nicias y Alcibíades. Madrid: Akal. 2000 [Edición de Javier Negrete Medina].

Sofistas. Obras. Madrid: Editorial Gredos. 2007. [Edición de Antonio Melero Bellido].

Tucídides. Historia de la Guerra del Peloponeso. Libros I-Il. Madrid: Editorial Gredos. 1990. [Edición de Juan José Torres Esbarranch]. 


\section{Panta Rei}

PANTA REI es una revista digital de investigación orientada a la Historia y otras ciencias afines. Su principal objetivo es la transmisión del conocimiento científico, dando una oportunidad también a los jóvenes investigadores que quieren abrirse camino en el estudio de las ciencias humanas y sociales. Se compone de estudios originales relacionados con la disciplina histórica así como su didáctica y difusión. Las diferentes secciones que componen la revista son: artículos de investigación, entrevistas a profesionales, recensiones de monografías de actualidad y crónicas de congresos o eventos científicos relevantes.

Todos los artículos publicados son objeto de un proceso de revisión a cargo de un mínimo de dos evaluadores, que se consideran expertos en el ámbito temático del artículo propuesto. Nuestro deseo es poder ofrecer unos contenidos rigurosos, de calidad y de interés.

EI CEPOAT (Centro de Estudios del Próximo Oriente y la Antigüedad Tardía de la Universidad de Murcia) es la institución encargada de la coordinación y gestión de la revista, desde donde anualmente se lanzará la convocatoria para aquellos que estén interesados en publicar sus trabajos, siempre relacionados con la Historia, Arqueología, Historia del Arte, Didáctica de las Ciencias Sociales, etc.

PANTA REI is a digital journal focused on History and other sciences related to it. Its main objective is the transmission of scientific knowledge by giving also an opportunity to young researchers who want to make their way in the study of human and social sciences. It is composed by original studies related to History, as well as its didactics and promotion. The different sections of this journal are: research articles, interviews to professionals, recensions on monographs about current issues and reports about congresses or relevant scientific events.

All the articles published are subject to a revision process carried out by a minimum of two reviewers who are considered to be experts in the field of the article proposed. Our wish is to offer rigorous contents with quality and being of interest to the reader.

CEPOAT (Centre of Studies of the Middle East and Late Antiquity of the University of Murcia) is the institution in charge of the coordination and management of this journal. This is the centre from where the call for papers will be launched for all the people interested in publishing their papers, always related to History, Archeology, Art History, Didactics of the Social Sciences, etc. 


\section{Normas de Publicación}

El autor se compromete a enviar trabajos originales, que no se encuentren publicados en otras revistas ni en otros idiomas. Así mismo, el mismo artículo no podrá ser presentado en otras revistas mientras dure el proceso de evaluación.

\section{Envío y presentación de originales}

Los artículos se enviarán exclusivamente a través del correo electrónico a la dirección pantarei@um.es. Los textos serán enviados en formato DOC y las imágenes en formato JPEG o TIFF, y con un tamaño mínimo de 2000 px. Éstas no aparecerán incorporadas en el texto, sino enviadas en archivo aparte y correctamente numeradas según su posición en el texto. Junto al trabajo, se rellenará y enviará un documento aparte en el que se especifiquen los datos del autor siguiendo el modelo disponible en la página Web de la revista.

Para la redacción de los trabajos se tendrá en cuenta el Manual de la American Psychological Association, en su sexta edición. La extensión máxima de los trabajos será de 30 páginas. La tipografía será Arial 11, con interlineado sencillo y sin espacio alguno entre párrafos. El texto deberá ir justificado a ambos márgenes y sin sangría en los primeros párrafos. Los márgenes serán de $2,50 \mathrm{~cm}$. En los casos en los que fuera necesario incorporar notas, éstas irán a pie de página, enumeradas consecutivamente, con tipografía Arial 10, interlineado sencillo y justificadas a ambos márgenes.

Una información más detallada se encuentra disponible en la página http://www.um.es/cepoat/ pantarei.

\section{Proceso de valoración y evaluación}

Una vez recibidos los trabajos, la Revista realizará una primera valoración. Si el trabajo enviado se ajusta a las normas de presentación propuestas, la temática es coincidente con la línea editorial de la revista y posee la calidad científica necesaria, será remitido al consejo asesor para una primera evaluación. Si no es así en este primer paso se puede rechazar directamente los documentos que incumplan claramente la línea editorial.

Será el Consejo Asesor quien indique a la revista la originalidad, relevancia, estructura, redacción, aparato bibliográfico, etc. del trabajo enviado y, para ello, se designará a dos revisores expertos externos que evaluarán cada uno de los trabajos, que pueden formar parte (o no) de este Consejo Asesor. La selección de los revisores se ajustará a la temática y características metodológicas del trabajo. El nombre y filiación de los autores serán eliminados del trabajo para su revisión, así como los revisores actuarán de manera anónima y confidencial.

Los revisores deberán rellenar un informe de evaluación que centrará su atención en aspectos tales como características formales, originalidad y novedad de los trabajos, relevancia de las propuestas y los resultados, calidad metodológica y validez científica.

Una vez terminado el proceso se decidirá la aceptación o no de los mismos y su publicación en el número que sea pertinente, así como las modificaciones susceptibles de ser realizadas para su final publicación. Dicha notificación se enviará únicamente por correo electrónico, en un plazo máximo de seis meses. 


\section{Publishing rules}

The author is committed to submit original papers not having been published in other reviews or in other languages. In this way, it is not allowed for the same paper to be presented in other reviews during the evaluation process.

\section{Submission and presentation of originals}

The articles will be exclusively submitted by email to pantarei@um.es. The texts will be submitted in DOC format and the images in JPEG or TIFF format, and with a minimum size of 2000 px. Images will not be integrated in the text but sent in another file and properly numbered according to their position in the text. Attached to the paper, a document will be filled out and sent where the author's data will be specified following the model available on the website.

The sixth edition of the Manual of the American Psychological Association will be taken into account for the writing of the papers. The length of the papers must not exceed 30 pages. Typography will be Arial 11 , with simple line spacing and no space between paragraphs. The text must be justified on both margins without indentation in the first paragraphs. Margins size will be $2.50 \mathrm{~cm}$. Where it could be necessary the incorporation of notes, they will be at the bottom of the page, consecutively numbered with typography Arial 10, simple line spacing and justified on both margins.

More detailed information is available on the website: http://www.um.es/cepoat/pantarei.

\section{Examination and assessment process}

The Journal will submit the papers to a first examination once received. If the paper follows the presentation guidelines, the subject agrees with the editorial line of this journal, and possess the scientific quality required, it will be sent to the advisory council for a first assessment. If not, the documents which clearly fail to complete the editorial line may be rejected straightaway in this first step.

The Advisory Council will indicate the originality, relevance, structure, writing, bibliography, etc. of the text to the journal; for this purpose, two outside experts will be designated to review the papers; these experts can be (or not) part of this Advisory Council. The selection of the experts will adjust to the subject and methodological characteristics of the paper. Name and affiliation of the author will be eliminated from the text for its review, in this way experts will act anonymously and confidentially.

The experts will fill out an assessment report which will focus on aspects such as formal characteristics, originality and novelty of the papers, relevance and results of the proposal, methodological quality and scientific validity.

Once the process is finished, the acceptance or not of the papers and its publication in the corresponding edition will be decided, as well as the modifications that may be done for its final publication. This notification will be sent by email within 6 months maximum. 


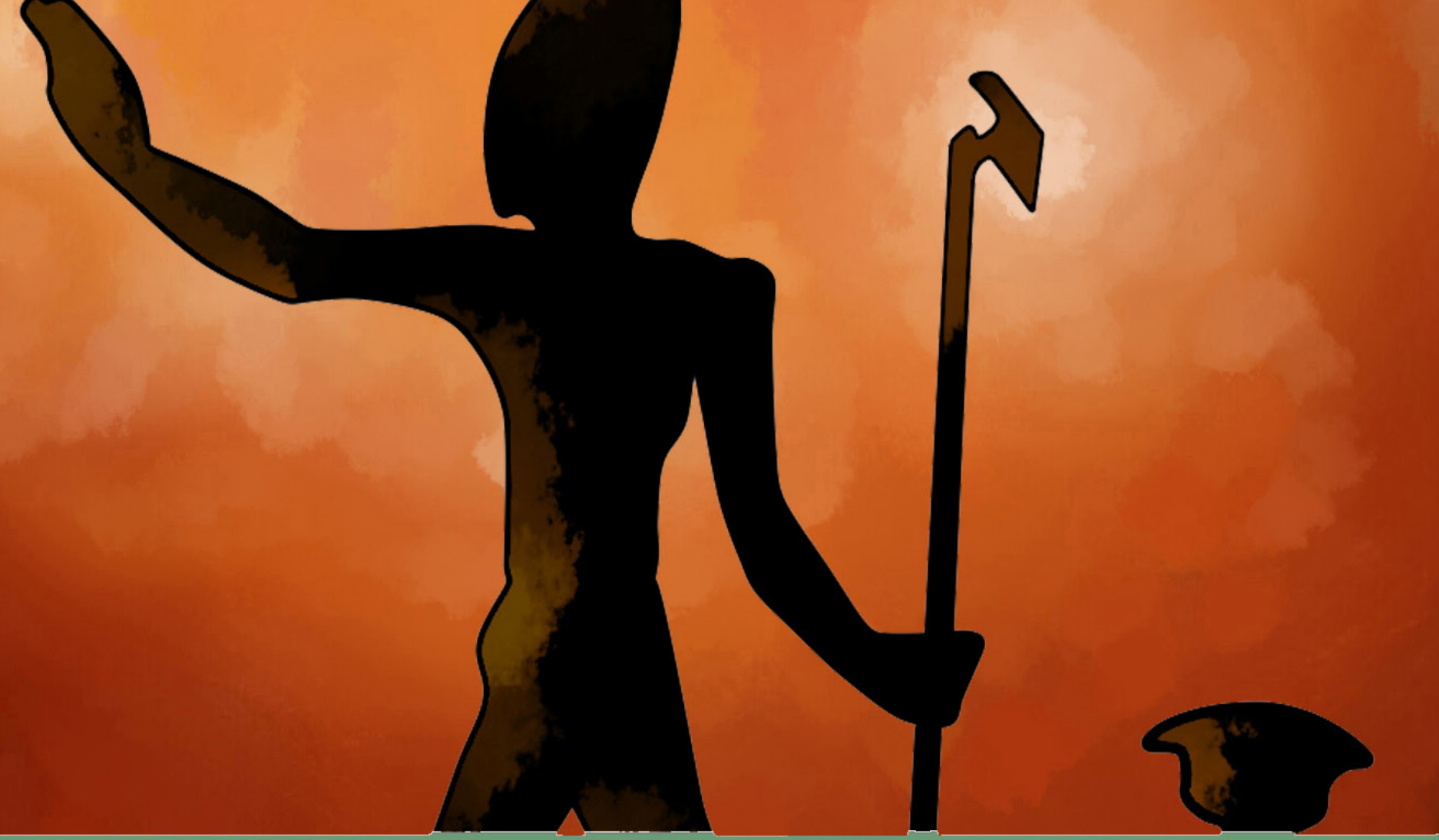

\section{cepot}

UNIVERSIDADD DE MURCIA

centro de estudios del

próximo oriente y la

antigüedad tardía 